\title{
Who's in charge? How voters attribute responsibility in the European Union
}

As an emerging federal system, the European Union (EU) divides decision-making powers between multiple levels of government. Yet little is known about how EU citizens attribute responsibility to the EU. In particular, do people hold the EU, rather than national governments, responsible for different policy outcomes, some of which are primarily decided at the EU level? This article investigates the extent to which institutional differences and individual biases influence citizens' attribution of responsibility in the European Union. We rely on unique survey data collected in all $27 \mathrm{EU}$ member states to explore how citizens attribute responsibility across five different policy areas. Employing a multilevel model of responsibility judgments, our findings show that while citizens' evaluations correspond to the institutional context, group-serving biases, related to support for the EU, have a more important role in shaping attributions of responsibility in the EU. 
Who's in charge? Who should citizens blame when things go wrong, and who should they credit when things go right? These are crucial questions in any democratic system, not least in systems of multi-level governance where it is particularly challenging to identify exactly which level of government is responsible. Yet, little is currently known about how voters attribute responsibility to different levels of government in multi-level systems, and almost nothing is known about responsibility judgments within the European Union (EU). The governance system of the EU presents a particularly daunting task to citizens, as the institutions and divisions of competences are continuously evolving and changing. The raises the question addressed in this article: how do citizens assign responsibility across levels of government in the EU? Our argument is that while the institutional context structures responsibility attributions to an extent, individuals' rely heavily on their own subjective biases when forming opinions on whether the EU or their national government is responsible for policy outcomes. Crucially, we identify an important "perceptual screen", namely people's predispositions about the European Union, which moderates individuals' responsibility attributions.

Numerous comparative studies have shown that complex institutional structures that blur lines of responsibility make it difficult for voters to hold governments to account (Anderson 2000; De Vries et al 2011; Hellwig 2001; Hellwig and Samuels 2008; Powell 2000; Powell and Whitten 1993; Whitten and Palmer 1999). Empirically, these studies have demonstrated that clarity of responsibility conditions the extent to which voters sanction governments on the basis of economic outcomes. Yet little of this work has directly examined voters' views of who is actually responsible. What recent work there is has focused on the federal systems of Canada and the US (Arcenaux 2006; Cutler 2004, 2008; Rudolph 2003, 2003a), finding that both the institutional context and individual-level predispositions, notably partisanship, shape citizens’ responsibility judgments. 
This paper extends the existing literature by examining attribution of responsibility in a more comparative context, presenting the first comprehensive study of how people assign political responsibility in the EU. The EU provides the ideal "laboratory" for examining the impact of institutions on responsibility judgments. It not only presents a very challenging context in which citizens need to make decisions about responsibilities, but also allows us to examine citizens across 27 countries with considerable variation in both national political institutions and in levels of federal (EU) power. This study analyzes a unique module of survey questions designed specifically to uncover citizens' opinions on responsibility, conducted in all 27 EU member states after the 2009 European Parliament elections. It makes a number of contributions to the literature. First, as a large-scale comparative study of responsibility judgments it enhances our understanding of the role of institutions by demonstrating that the divisions of power between institutions do at least partially shape how voters assign responsibility. Second, unlike most studies of attribution and performance voting we move beyond simply the economy to examine responsibility judgments across a range of policy domains: the economy, monetary policy, health care, immigration, and climate change. Third, we demonstrate that partisanship is not the only 'in-group' that moderates the effect of performance evaluations on attribution: support for the EU also forms the basis of a group-serving attribution bias. Finally, and more generally, by examining a hitherto largely overlooked aspect of European integration, we hope to contribute to the understanding of evolving electoral democracy in the EU.

\section{Who's responsible in multi-level systems?}

In the classic reward-punishment model of electoral accountability, voters re-elect incumbents who have performed well, but oust those who have performed badly (Key 1966; Powell 2000). Yet this claim of a clear link between policy performance and vote choice has 
been called into question by scholars focusing on how voters assign political responsibility. First from an institutional perspective, studies have shown that institutional clarity of responsibility conditions voters' ability to make judgments about who is responsible for policy outcomes, and to sanction incumbents accordingly. Second from an individual-level perspective, scholars have argued that responsibility judgments are influenced by 'groupserving attribution biases', such as partisanship, which shape the link between policy evaluations, assignment of responsibility and vote choices.

Both of these points are relevant if we want to understand how people assign responsibility in multi-level systems of government. Starting with the institutional perspective, an extensive body of work suggests that the degree to which incumbents are held to account for economic performance (objective or subjective) is conditioned by a system's institutional context. In their seminal article, Powell and Whitten (1993) demonstrate that elections in countries where responsibility is most easily focused on a single party are more likely to follow the reward-punishment model. Other comparative analyses of economic voting have supported the more general claim that economic voting is less prevalent when governments are weak and divided and legislatures are strong (Anderson 2000; Hellwig and Samuels 2008; Whitten and Palmer 1999; Duch and Stevenson 2008). Much of the most recent work has also focused on the 'vertical' institutional structures of federal government, arguing that multiple levels of government make it difficult for voters to assign responsibilities for the policy outcomes as they find it difficult to know which level of government is responsible (Arceneaux 2006; Cutler 2004, 2008; Johns 2010).

This 'clarity of responsibility' extension to the simple reward-punishment model focuses on context-level differences, but other work has shifted the focus to the individual level and have criticized the portrayal of vote choice as a simple function of policy performance (e.g. Rudolph 2003: 699). Instead, it has been argued that voters’ responsibility 
judgments are conditioned by their prior political beliefs, primarily their partisanship. ${ }^{1}$ This idea builds on the social psychology notion of 'group-serving attribution bias', which refers to the tendency of in-group members to attribute positive actions committed by their own group to positive in-group qualities and negative actions by the favored group to external causes (Pettigrew 1979; Hewstone 1989; Fiske and Taylor 2007). This in-group bias has been found in a number of contexts, and in the political science literature, studies have looked at how partisanship influences both political attitudes generally, but also specifically attributions of responsibility (Campbell et al. 1960; Abramowitz 1988; Feldman 1982; LewisBeck 1997; Peffley 1984; Sigelman and Knight 1985). Rudolph has shown that partisanship is a significant driver of who is thought responsible for the economy and such responsibility judgments in turn act as an important moderator of economic evaluations in predicting vote choices (Rudolph 2003, 2003a). The importance of partisanship in shaping citizens' responsibility judgments has also been demonstrated in work on the economy and public services in Britain and Ireland (Marsh and Tilley 2010; Tilley and Hobolt 2011) and on assignment of responsibility for the response to Hurricane Katrina in 2008 (Gomez and Wilson 2008; Maestas et al. 2008; Malhotra and Kuo 2008). This next section extends this literature by developing a set of theoretical expectations about how individual-level and contextual-level factors shape attribution of responsibility in the European Union.

\section{Who's responsible in the EU?}

Over the past decades, the scope and depth of policy-making in the multi-level European Union has increased to the point that it has many traits in common with a federal state (Kohler-Koch 1996; Hooghe and Marks 2003). European voters consequently face considerable challenges when deciding whether policy outcomes are the responsibility of the national (or indeed local) government or the EU institutions, just as they do in more 
established federal states such as the US and Canada. Yet despite the increasingly federal nature of the EU there has been little research investigating whether citizens realize the degree to which policy decisions that affect their day-to-day lives are now taken in Brussels. More importantly, we also have a very limited understanding of how citizens arrive at responsibility judgments in the context of divided authority within the EU.

Attributing responsibility correctly in multi-level systems is a daunting task. Not only may voters have difficulty figuring out who is responsible for what, but politicians will have strong incentives to engage in blame shifting and credit taking that will further serve to undermine clear responsibility linkages. Cutler $(2004,2008)$ has shown that voters do not strongly differentiate between the governments' roles across issues in Canada. Similarly León's (2010) study of Spain demonstrates that citizens in regions with a more intertwined distribution of power find it most difficult to assign responsibility correctly. At the same time, Johns (2010) has also shown that voters in Ontario and Scotland can fairly accurately assign issues to different levels of government, and a number of studies in the US have reached more optimistic conclusions about voters' ability to distinguish between the responsibility of different levels of government (Atkeson and Partin 1995, 1998; Niemi et al 1995; Arceneaux 2006). For example, Arceneaux (2006) finds that, at least for salient and accessible issues, people are capable of both making distinctions between different levels of government and that those distinctions structure how voters attribute credit or blame for policy outcomes. This raises the question of whether European citizens incorporate information about divisions of power between the national and the European level into their attribution of responsibility, or whether these judgments are insensitive to the institutional context.

Impact of the institutional context 
Responsibility for most policy outcomes in the European Union is shared between national and EU institutions (as well of course by other governmental and non-governmental actors) and policy outcomes may thus legitimately be attributed to either level. Nonetheless, it is reasonable to argue that there are certain features of national and EU institutions that make attribution of responsibility to either level of government more or less likely. The EU's Lisbon Treaty, ratified in December 2009, made an attempt to clarify divisions of power in the EU by distinguishing between exclusive, shared and complementary competences of the EU. ${ }^{2}$ To the extent that people's perceptions of power correspond to these divisions, we would expect that they attribute greater responsibility to the EU in areas of exclusive competences $^{3}$ (e.g. monetary policy and competition policy) than in areas of complementary competences (e.g. health policy and foreign policy). But even for policy areas within the same broad category, there is still considerable variation in actual policy activities and most competences are both overlapping and evolving over time.

The influence of EU institutions varies not only across policy domains, but also across member states in systematic ways. Not all member states have transferred equal powers to the EU. The most obvious example is the EU's Economic and Monetary Union (EMU), which established a currency union (the Eurozone) in 1999, and currently contains 17 of the EU's 27 members. ${ }^{4}$ Since the European Central Bank (ECB) has exclusive competence over monetary policy in Eurozone countries with the EU's Council setting fiscal guidelines, ${ }^{5}$ we would expect that citizens in Eurozone countries would attribute greater responsibility to the EU in the area of economic policy-making, and particularly monetary policy. Differentiated, or flexible, integration has become an important feature of European integration since the 1990s and there are various examples of 'opt-outs' granted to specific countries in policy domains (see Holzinger and Schimmelfenig 2012). ${ }^{6}$ Generally, we would expect citizens in 
countries with such opt-outs would attribute less responsibility to the EU in the relevant policy domain. This leads to our first hypothesis:

H1a: People in countries with an opt-out from an EU policy domain attribute relatively less responsibility to the EU in that domain than people in countries without an opt-out.

However, to understand how institutions shape attribution in this multi-level system, it is not sufficient to focus on the EU's decision-making ability. We also need to explore variation in the national institutional context. After all, there are significant differences across the EU in the role that national governments play. For example, some countries have large government funded health care systems, whereas others have largely private insurance based systems. All things being equal, we would expect that citizens in the former would attribute more responsibility to national governments and relatively less responsibility to the EU for policy outcomes in health care policy. In general, we would therefore expect that higher levels of national government activity in a particular policy area would lead to greater attribution of responsibility to national governments relative to the EU level.

H1b: People in countries with higher levels of government activity in a policy domain attribute relatively less responsibility to the EU for policy outcomes in that domain compared to people in countries with lower levels of national government activity.

Next, we turn to the question of how individuals' predispositions shape their attribution of responsibility. 


\section{Impact of group-serving biases}

Few studies have explicitly examined how 'perceptual biases' may influence the way in which people assign responsibility in a federal context. Exceptions are studies by Rudolph (2003) and Brown (2010), which show that for American voters partisanship is an important moderator of the effect of evaluations of performance on attribution of responsibility. That is, people appear to engage in partisan rationalization when they attribute responsibility for fiscal conditions in states, with partisans of the governor's party more likely to attribute responsibility to the governor for, say, improving economic conditions. We expect similar group-serving attribution biases to influence how voters assign responsibility in the EU. The main difference in the context of the EU is that when responsibility is assigned to more than one level, partisanship might not be the only ‘in-group’ of importance.

At the national level, we would expect partisanship to be a factor conditioning whether or not voters decide to hold the government responsible for policy performance. But when it comes to the EU level, partisanship is not expected to be a decisive factor, since the EU has a mixed, collective executive consisting of delegates of different political persuasions from all member states. It is therefore very difficult to identify a specific 'partisan' affiliation of the Council, or even the Commission (Føllesdal and Hix 2006). Instead research has shown that the primary factor determining attitudes towards policies at the European level is general attitudes towards the EU, which in turn are largely driven by identity concerns (McLaren 2006; Hooghe and Marks 2005, 2009). In other words, the 'nation’ versus 'Europe' may be regarded as a salient in-group/out-group division in this context. Typically people who have more exclusive national identities are less likely to be in favor of European integration (Carey 2002; Hooghe and Marks 2005; McLaren 2006). ${ }^{7}$ In that sense support for or opposition to the EU is seen as deeply rooted in people's conceptions of their own (national) identity. That means that we would expect that feelings about the EU will affect 
responsibility judgments in a similar manner to partisanship. Partisanship and EU support are not identical types of predispositions, but they may well act in a similar way. People who are negatively disposed towards the EU as a level of government will be more likely to attribute responsibility to the EU when things are going badly, just like opposition partisans will be more likely to blame the domestic government for a crisis.

H2: Regardless of partisanship, people who support the EU project are more likely to attribute responsibility to the EU when conditions are improving and less likely when conditions are deteriorating.

The next section discusses how we test these hypotheses empirically.

\section{Data and methods}

To examine responsibility judgments in the European Union, we designed a module of questions on attribution of responsibility, conducted as a part of the European Election Studies (EES) 2009. The EES is a cross-national survey of all 27 EU member states, with a nationally representative sample of around 1,000 respondents in each country. The dependent variable in our analysis is the degree to which respondents assign responsibility to the EU over the national level government for a particular policy-domain, with five policy areas in total. Since our objective is to examine how voters assign responsibility to different levels of government in a multi-level system, we measure attribution of responsibility to the EU level of government relative to the attribution of responsibility to the national level government. We refer to this as net EU attribution. The question wording can be illustrated with these questions asked to British respondents about the economy: 
Now I would like to ask you some questions about how much responsibility the British government and the European Union have for some of the things going on in Britain. Of course, you may think that neither is responsible. First, thinking about the economy, how responsible is the British government for economic conditions in Britain? Please indicate your views using any number on a scale from 0 to 10, where 0 means "no responsibility" and 10 means "full responsibility”.

And what about the European Union, how responsible is the EU for economic conditions in Britain?

Each dependent variable has been operationalized as a net EU attribution score - that is, the 'EU attribution score’ minus 'national government attribution score' - since we are interested in capturing the relative level of responsibility that people attribute to each level of government. This means that in principle the net EU attribution score runs from -10 to +10 for each policy area, where +10 indicates that only the $\mathrm{EU}$ is responsible and -10 that only the national government is responsible, although in practice around three quarters of respondents score within a range three points higher and three points lower than the mean. ${ }^{8}$ Similar questions were asked for four other policy areas: interest rates, health care, immigration and climate change. These five policy areas provide variation on several dimensions of interest. First, in the areas of the economy, interest rate and immigration, there is variation in the degree to which the EU has influence over member states due to the opt-out provisions described above. Second, whereas interest rates can be characterized as an 'exclusive competence' of the EU for Eurozone members, health care and most aspects of immigration and climate change fit more squarely within the category of 'complementary competences'. 
Finally, there is considerable variation in member state activity in individual policy domains, such as health care and climate change.

Table 1 shows the descriptive statistics for three scales (national government attribution, EU attribution and net EU attribution) across policy domains for all respondents. The table also reports standard deviations, which are similar across the national and EU attribution scales. As we would expect people tend to attribute more responsibility to the EU in policy areas where the EU has exclusive competences than in areas where they have only complementary/coordination competences. The highest responsibility attributions for national governments and the lowest responsibility attributions for the EU are for health care, in contrast to climate change and interest rates where the two levels of governments, on average, are perceived to be almost equally responsible. Overall national governments are seen as more responsible in all five areas, although only marginally so in the case of climate change. ${ }^{9}$

\section{TABLE 1 ABOUT HERE}

This ranking of net EU attribution is in line with expectations and thus these descriptive statistics lend some support to the expectation that institutional context has an impact on EU attribution. The next step is to specify a statistical model that can be estimated to explain variation in net EU attribution both within countries and across countries. Since individual respondents are nested within national surveys, we estimate multilevel (random effects) models. As discussed, we are interested in both the individual-level correlates of EU attribution, but also in how the institutional context, at both the EU and national level, shape responsibility judgments. To test hypotheses $1 \mathrm{a}$ and $1 \mathrm{~b}$ we include variables that capture the variation of EU involvement across member states for some policy areas, and national government control for other policy areas. To measure the degree of EU involvement in the 
economy, and particularly monetary policy, we include a dummy for all Eurozone outsiders. The degree of EU involvement in the area of immigration is captured by a dummy for those countries who do not participate in the Schengen border-free zone (UK and Ireland) or who have another opt-out relating to common immigration policy (Denmark). The EU's influence in the areas of health care and climate change does not vary across countries, however, we capture variation in the policy-specific institutional context by measuring the varying levels of activity by national governments. To measure the level of government involvement in health care, we include a measure of national government spending on health care (as a percentage of all spending). To measure the level of government involvement in efforts to deal with climate change, we include a dummy for countries that have adopted National Adaptation Strategies (NAS) on climate change, which is a detailed strategy for how to deal with climate change at the national level.

Finally, we control for the size of the economy, since it may be argued that larger economies and richer countries have more powerful national institutions relative to the $\mathrm{EU},{ }^{10}$ and also for the quality of national institutions as people may assign less responsibility to poorer quality national institutions (Rohrschneider 2002). The first is measured by total GDP of the country in trillions of US dollars, and the second is measured using an additive scale (Cronbach's alpha 0.96) of the World Bank's five governance indicators on voice and accountability, government effectiveness, regulatory quality, rule of law, and control of corruption (see Kaufmann et al. 2009).

At the individual level, we hypothesized that net EU attribution will be influenced by support for the European Union, which is operationalized as an additive scale, based on four questions tapping into respondents' feelings about the EU and the European integration project. ${ }^{11}$ To test hypothesis 2 , concerning group-serving attribution bias, it is necessary to evaluate whether EU support conditions the effect of performance on attribution. 
Retrospective performance evaluations were measured separately for each of the five policy areas on a 1-5 scale with 1 representing a lot worse and 5 a lot better. We control for partisanship, which is measured by a dummy for government partisans, that is respondents who say they feel closer to one of the national government parties. ${ }^{12}$ To assess the moderating effect of both types of attribution bias, we include two interaction terms in our models: one between EU support and policy evaluation and one between partisanship and policy evaluation. We also control for political knowledge at the individual level, since more politically knowledgeable people might be expected to be better able to distinguish between the responsibilities of different levels of government. ${ }^{13}$ Political knowledge was measured as an additive scale using a set of 7 factual knowledge questions relating to national governments and the EU and is group-mean centered. (All question wordings and descriptive statistics can be found in the appendix.)

\section{Results}

Across each of the five policy areas, we run a hierarchical linear model to test our propositions. This model contains both contextual variables to test the effects of the EU (hypothesis 1a) and national context (hypothesis $1 \mathrm{~b}$ ), as well as individual-level predictors to test the group-serving attribution bias (hypothesis 2). Table 2 shows this model run separately for each of the five different issue areas.

\section{TABLE 2 ABOUT HERE}

First, the impact of the national and EU institutional context on net EU attribution is clear. Policy-specific institutions influence net EU attribution as hypothesis 1a suggested. Unsurprisingly, we see a large effect for Eurozone outsiders, as citizens in countries not 
belonging to the Eurozone attribute significantly less responsibility to the EU than citizens within the Eurozone. For the economy, being outside the Eurozone subtracts nearly one point from the average EU net attribution score. As we would expect given that Eurozone membership has a greater effect on monetary policy than fiscal policy at the time of the survey, this effect is even more pronounced for the policy domain of interest rates. On average, ${ }^{14}$ people living in countries outside the Eurozone attribute more responsibility to their national governments than the EU (scoring -1.5 on our scale), whereas people living in Eurozone countries attribute more responsibility to the EU than their national government (scoring 0.3 on our scale). By contrast, we find no significant effect of living in one of the countries with an immigration related opt-out (Denmark, Ireland and the UK) on attributed responsibility in the field of immigration. This may be because a common immigration policy has yet to be fully established at the EU level.

Turning to policy-specific institutions at the national level, we also find support for our hypothesis that higher levels of national government activity in a policy-domain lead to a lower net EU responsibility attribution (hypothesis 1b). In particular, a larger governmentfunded health care sector leads to lower net EU responsibility attribution for healthcare and National Adaptation Strategies for climate change lead to a lower net EU responsibility attribution for climate change. These effects are not quite as big as those for Eurozone membership, but they are not trivial. In countries where the proportion of spending on healthcare that is public is one standard deviation below the mean (for example, Greece or Latvia) the average EU net responsibility attribution is around 0.75 of a point higher than in countries where the proportion of spending on healthcare by the state is one standard deviation above the mean (for example, the Netherlands or Sweden). A national adaptation strategy for climate change similarly moves attributed responsibility away from the EU towards the national government, in this case by 0.4 of a point. 
These institutional effects are important, but people's responsibility attributions are not simply a product of the way in which real institutions vary. Table 2 also shows that they depend on the 'perceptual screens' that people view the world through. First, as shown in the extant literature, there is some evidence that partisanship matters, since government partisans are more likely to absolve their own governments of responsibility and shift the blame to the EU level by attributing relatively more responsibility to the EU as they perceive conditions to worsen. Yet, we only find this conditioning relationship to be statistically significant in two of the five policy domains of monetary policy and immigration. For the economy and healthcare there appears little effect of partisanship, and in fact for climate change the effect of partisanship is signed in the opposite direction to that which we would expect. Second, the control variable of political awareness has a significant impact on EU attribution in all of the models. The direction of this effect differs depending on the policy domain however: politically aware citizens are more likely to attribute responsibility to the EU for interest rates and, to some extent, climate change, and are less likely to attribute responsibility to the EU for the economy, health care and immigration. ${ }^{15}$

Of most interest are the interactions between EU support and evaluation. These are statistically significant across all policy areas except climate change and give strong support for hypothesis 2. This demonstrates that people who support the EU are more likely to attribute responsibility to the EU when conditions are improving and less likely when conditions are worsening. To illustrate how EU support conditions the effect of performance evaluations on EU attribution, we graph the marginal effect of performance evaluation on net EU attribution changes across different levels of EU support in Figures 1a to 1d (based on estimates from Table 2).

FIGURE 1 ABOUT HERE 
The solid sloping line (with 95\% confidence intervals around the line) in each of the figures indicates how the marginal effect of performance evaluations on net EU attribution changes an individual's level of EU support. Figure 1d (health care) and Figure 1c (immigration) show the strongest support for hypothesis 2 . These graphs clearly illustrate that the effect of performance evaluation on net EU attribution is moderated by levels of EU support: the marginal effect is positive for EU supporters and negative for Euroskeptics, as we would expect. We also find a conditioning impact of EU support on the effect of performance evaluation on attribution in the two economic policy domains, the economy (Figure 1a) and interest rates (Figure 1b). But surprisingly, for Euroskeptics there is no negative effect on net attribution when they perceive economic conditions to be improving. Rather, we just see an increasing attribution of responsibility to the EU as conditions improve for those that like the EU.

These effects are of comparable magnitude and generally of greater magnitude than the effects of different institutions that we saw earlier. For example, for an individual who strongly supports the EU (scoring 1 on our scale) the effect of moving from the worst to best economic outlook reduces his net responsibility score by 1.3 points, yet for someone else who is opposed to the EU (scoring 0 on our scale) economic conditions make almost no difference, the effect is negligible. There are similarly sized effects for interest rates and slightly larger ones for immigration. For health care, these effects are even more sizable. For EU enthusiasts (again scoring 1), moving from worst to best makes people 1.7 points more likely to claim the EU is responsible. For EU opponents (again scoring 0), the opposite effect is found. Moving from worst to best conditions makes people 1.2 points less likely to claim the EU is responsible. Overall, therefore we find strong support for hypothesis 2, and if anything these findings suggest that 'EU' versus 'the nation' not only acts as a stronger in- 
group/out-group distinction in the context of attribution across levels of governance in the EU than partisanship, but may be more important than real institutional differences between countries.

\section{Conclusion}

In this study, we have examined how citizens assign responsibility to different levels of government in the EU. Despite the complex and dynamic nature of the EU, European citizens do appear capable of making distinctions in terms of what different levels of governments do, and their responsibility judgments are shaped by the institutional context. We have demonstrated here that not only can citizens distinguish between the EU's degree of responsibility across policy domains, they are also responsive to the institutional context at both the national and the EU level of government. It is evident that citizens in countries outside the Eurozone attribute less responsibility to the EU for the economy in general and monetary policy-making in particular. We also find that citizens in countries with an active involvement in specific policy areas, in particular large government-funded health care sectors and national strategies to deal with climate change, attribute less responsibility to the EU relative to their national government in these policy domains. These findings suggest that when division of responsibilities are clear, citizens' perceptions of political responsibility are at least partially influenced by the institutional context.

However, while the institutional context helps to structure responsibility judgments in the EU, we also find that group-serving biases are a powerful driver of people's assignments of responsibility. Whereas the extant literature has focused almost exclusively on the role of partisanship (e.g. Rudolph 2003, Gomez and Wilson 2008; Maestas et al. 2008; Tilley and Hobolt 2011), we highlight another type of 'in-group/out-group' distinction that is particularly salient in the EU. This is the distinction between those individuals who feel 
exclusively attached to their nation, and do not want to surrender sovereignty to the EU level of government, and those who feel more positive towards European integration. Our results show that this distinction serves as a powerful moderator of responsibility judgments: EU enthusiasts are more likely to attribute responsibility to the EU when conditions are improving, whereas Euroskeptics tend to deny the EU any responsibility for positive outcomes. This demonstrates that even in complex systems of governance lacking a federallevel partisan executive citizens still rely on political predispositions when assigning responsibility. The difference here is that these political predispositions are not related to political parties, but rather feelings towards the institutions themselves. This study thus contributes to the extant literature on citizen attribution in complex institutional environments that has either ignored in-group biases, or focused exclusively on the role of partisanship.

What are the normative implications of these findings? Previous literature has emphasized the usefulness of heuristics, such as prior political attachments, in overcoming informational shortfalls and navigating complex democratic processes (McKelvey and Ordeshook; Lupia and McCubbins 1998). However, the impact of group-serving attribution biases identified in this study should be viewed as a potential threat to democratic accountability in the EU, rather than as a means of overcoming voter ignorance. The reliance of prior predispositions about the EU to navigate the complex structures of governance in the EU can lead to grave “attribution errors” (Pettigrew 1979), as Euroskeptics are more likely to absolve their national governments of any responsibility for poor performance, even in instances where they are to blame, and equally pro-Europeans are prone to credit the EU with improving policy conditions even in cases where the responsibility lies almost exclusively at the national level. A prevalent effect of in-group biases thus cast into doubt the ability of voters to hold politicians to account for the policy outcomes that they are responsible for in this multi-level government context. 
This potentially has serious implications for democratic processes in the European Union both at the national and at the EU level. First, politicians at both levels may exploit the existence of complex institutions and in-group biases to seek to attach credit to their own institutions and shift blame to other institutions. Second, the classic reward-punishment model of elections as a means of voters punishing politicians for poor performance and crediting them for favourable conditions only functions to the extent that citizens can attribute responsibility correctly and rely on these attributions when casting their ballot. While examining the influence of responsibility evaluations on vote choice is beyond the scope of this paper, our findings have highlighted that responsibility evaluations are only partially a reflection of actual divisions of responsibilities and are significantly shaped by people's feelings about that EU. This suggests that standard notions of electoral accountability based on performance voting are potentially threatened by the complexity and fluidity of the EU's multi-level system of government. 


\section{References}

Abramowitz, Alan I., David J. Lanoue and Subha Ramesh (1988), 'Economic conditions, causal attributions, and political evaluations in the 1984 Presidential election', The Journal of Politics 50: 848-863.

Anderson, Christopher J. (2000), 'Economic voting and political context: A comparative perspective’, Electoral Studies 19: 151-170.

Arceneaux, Kevin (2006), 'The federal face of voting: Are elected officials held accountable for the functions relevant to their office?', Political Psychology 27: 731-745.

Atkeson, Lonna Rae and Randall W. Partin. (1998). 'Economic and Referendum Voting and the Problem of Data Choice: A Reply.' American Journal of Political Science, 42 (3): 1003-7.

Atkeson, Lonna Rae and Randall W. Partin. (1995). 'Economic and Referendum Voting: A Comparison of Gubernatorial and Senatorial Elections.' American Political Science Review, 89 (1): 99-107.

Brown, Adam R. (2010), 'Are governors responsible for the state economy?' Partisanship, blame, and divided federalism', Journal of Politics 72(3): 605-615.

Campbell, Angus, Philip Converse, Warren Miller and Donald E. Stokes (1960), The American Voter. Chicago: University of Chicago Press.

Carey, Sean (2002), 'Undivided Loyalties: Is National Identity an Obstacle to European Integration?' , European Union Politics 3(4): 387-413.

Cutler, Fred (2004), 'Government responsibility and electoral accountability in federations', Publius: The Journal of Federalism 34: 19-38.

Cutler, Fred (2008), 'Whodunnit? Voters and responsibility in Canadian federalism', Canadian Journal of Political Science, 41: 627-654. 
De Vries, Catherine, Erica E. Edwards \& Erik R. Tillman (2011), Clarity of Responsibility Beyond the Pocketbook: How Political Institutions Condition EU Issue Voting. Comparative Political Studies 44(3): 339-363.

Duch, Raymond M. and Randy Stevenson (2008), The Economic Vote: How Political and Economic Institutions Condition Election Results (Cambridge: Cambridge University Press).

EES (2009), European Parliament Election Study 2009, Voter Study, Advance Release, 01/05/2010, (www.piredeu.eu).

Evans, Geoffrey and Robert Andersen (2006), 'The political conditioning of economic perceptions: Evidence from the 1992-97 British electoral cycle', The Journal of Politics 68: 194-207.

Feldman, Stanley (1982), 'Economic self-interest and political behavior.' American Journal of Political Science 26: 446-66.

Fiorina, Morris P. (1981), Retrospective Voting in American National Elections (New Haven: Yale University Press).

Fiske, Susan T. and Shelley E. Taylor (2007), Social Cognition. From Brains to Culture. (New York: McGraw-Hill).

Føllesdal, Andreas and Simon Hix (2006), 'Why There is a Democratic Deficit in the EU: A Response to Majone and Moravcsik', Journal of Common Market Studies 44(3) 533562.

Gabel, Matthew J. (1998) Interest and Integration. Market Liberalization, Public Opinion and European Union (Ann Arbor, MI: The University of Michigan Press).

Gomez, Brad T. and J. Matthew Wilson (2003), 'Causal attribution and economic voting in American congressional elections’, Political Research Quarterly 56: 271-282. 
Hellwig, Timothy T. (2001), 'Interdependence, government constraints, and economic voting', Journal of Politics 63: 1141-1162.

Hellwig, Timothy T. and David Samuels (2008), 'Electoral accountability and the variety of democratic regimes’, British Journal of Political Science 38: 65-90.

Hewstone, Miles (1989), Causal Attribution: From cognitive processes to collective beliefs (Oxford: Blackwell).

Holzinger, Katharina and Frank Schimmelfennig (2012), 'Differentiated integration in the European Union: Manu Concepts, Sparse Theory, Few Data', Journal of European Public Policy, 19(2): 292-305

Hooghe, Liesbet and Gary Marks (2003) 'Unraveling the Central State, but How? Types of Multi-Level Governance’, American Political Science Review, 97(2): 233-243.

Hooghe, Liesbet and Gary Marks (2005) 'Community, Calculation and Cues', European Union Politics 6(4): 421-445 .

Hooghe, Liesbet and Gary Marks (2009) 'A Postfunctionalist Theory of European Integration: From Permissive Consensus to Constraining Dissensus’, British Journal of Political Science 39(1), 1-23.

Johns, Robert (2010), 'Credit Where it's Due? Valence Politics, Attributions of Responsibility, and Multi-Level Elections', Political Behavior, forthcoming.

Kaufmann, Daniel , Aart Kraay and Massimo Mastruzzi (2009). 'Governance Matters VIII: Governance Indicators for 1996-2008’. World Bank Policy Research June 2009 Key, V.O. (1966), The Responsible Electorate (New York: Vintage).

Kohler-Koch, Beate (1996), 'Catching up with change: The transformation of governance in the European Union', Journal of European Public Policy, 3(3) 359 - 380

León, Sandra (2010), 'Who is responsible for what? Clarity of responsibilities in multilevel states: The case of Spain'. European Journal of Political Research, forthcoming 
Lewis-Beck, Michael S. (1997), 'Who's the chef? Economic voting under a dual executive', European Journal of Political Research 31, 315-326.

Lewis-Beck, Michael S., Richard Nadeau and Angelo Elias (2008), 'Economics, party, and the vote: Causality issues and panel data', American Journal of Political Science 52: 84-95.

Lupia, Arthur and Mathew D. McCubbins (1998), The Democratic Dilemma. Can Citizens Learn What They Need to Know? Cambridge: Cambridge University Press.

McElvey, Richard and Peter Ordeshook (1986), 'Information, Electoral Equilibria and the Democratic Ideal. Journal of Politics 48(4): 909-37.

McLaren, Lauren (2006), Identity, interests and attitudes to European integration (Basingstoke: Palgrave Macmillan, 2006)

Maestas, Cherie D., Lonna Rae Atkeson, Thomas Croom and Lisa A. Bryant (2008), 'Shifting the blame: Federalism, media, and public assignment of blame following Hurricane Katrina’, Publius 38: 609-632.

Malhotra, Neil and Alexander G. Kuo (2008), ‘Attributing Blame: The public’s response to Hurricane Katrina’, Journal of Politics 70: 120-135.

Marsh, Michael and James Tilley (2010) 'The attribution of credit and blame to governments and its impact on vote choice', British Journal of Political Science 40(1): 115-134.

Niemi, Richard G., Harold W. Stanley, and Ronald J. Vogel (1995), 'State Economies and State Taxes: Do Voters Hold Governors Accountable?’ American Journal of Political Science, 2539 (4): 936-57.

Peffley, Mark (1984), 'The voter as juror: Attributing responsibility for economic problems', Political Behavior 6: 275-294.

Pettigrew, Thomas F. (1979), 'The ultimate attribution error: Extending Allport's cognitive analysis of prejudice’, Personality and Social Psychology Bulletin, 5: 461-476. 
Powell, G. Bingham (2000). Elections as Instruments of Democracy. Majoritarian and Proportional Visions. (New Haven: Yale University Press).

Powell, G. Bingham and Guy D. Whitten (1993), 'A cross-national analysis of economic voting: Taking account of the political context', American Journal of Political Science 37: 391-414.

Rohrschneider, Robert (2002). The Democracy Deficit and Mass Support for an EU-wide Government. American Journal of Political Science, 46,2: 463-475.

Rudolph, Thomas J. (2003), 'Institutional context and the assignment of political responsibility’, Journal of Politics 65: 190-215.

Rudolph, Thomas J. (2003a), 'Who's responsible for the economy? The formation and consequences of responsibility attributions', American Journal of Political Science 47: 698-713.

Sigelman, Lee and Kathleen Knight (1985), 'Public opinion and Presidential responsibility for the economy: Understanding personalization’, Political Behavior 7: 167-191.

Tilley, James and Sara Hobolt (2011) 'Is the government to blame? An experimental test of how partisanship shapes perceptions of performance and responsibility', Journal of Politics 73(2): 316-330.

Van Egmond, Marcel H., Eliyahu Sapir, Wouter van der Brug, Sara B. Hobolt, Mark N. Franklin (2010), EES 2009 Voter Study Advance Release Notes. Amsterdam: University of Amsterdam.

Whitten, Guy D. and Harvey D. Palmer (1999), 'Cross-national analyses of economic voting', Electoral Studies 18:49-67.

Wlezien, Christopher, Mark Franklin and Daniel Twiggs (1997), 'Economic perceptions and vote choice: Disentangling the endogeneity’, Political Behavior 19: 7-17. 


\section{Tables and Figures}

Table 1: Attribution of responsibility across policy domains and levels of government

\begin{tabular}{|c|c|c|c|c|c|c|c|}
\hline & $\begin{array}{c}\text { National gov. } \\
\text { attribution }\end{array}$ & Std. dev & $\begin{array}{c}\text { EU } \\
\text { attribution }\end{array}$ & Std. dev & $\begin{array}{c}\text { Net EU } \\
\text { attribution }\end{array}$ & Std. dev & $N$ \\
\hline Climate change & 6.25 & 3.10 & 6.22 & 3.03 & -0.04 & 2.56 & 23918 \\
\hline Interest rates & 6.30 & 3.17 & 5.88 & 3.08 & -0.40 & 3.75 & 22253 \\
\hline Immigration & 7.23 & 2.81 & 6.00 & 3.03 & -1.25 & 3.29 & 23788 \\
\hline Economy & 7.19 & 2.72 & 5.70 & 2.70 & -1.50 & 3.08 & 25043 \\
\hline Health & 7.80 & 2.70 & 4.72 & 3.00 & -3.16 & 3.46 & 24044 \\
\hline
\end{tabular}


Table 2: Individual- and context-level determinants of responsibility attributions

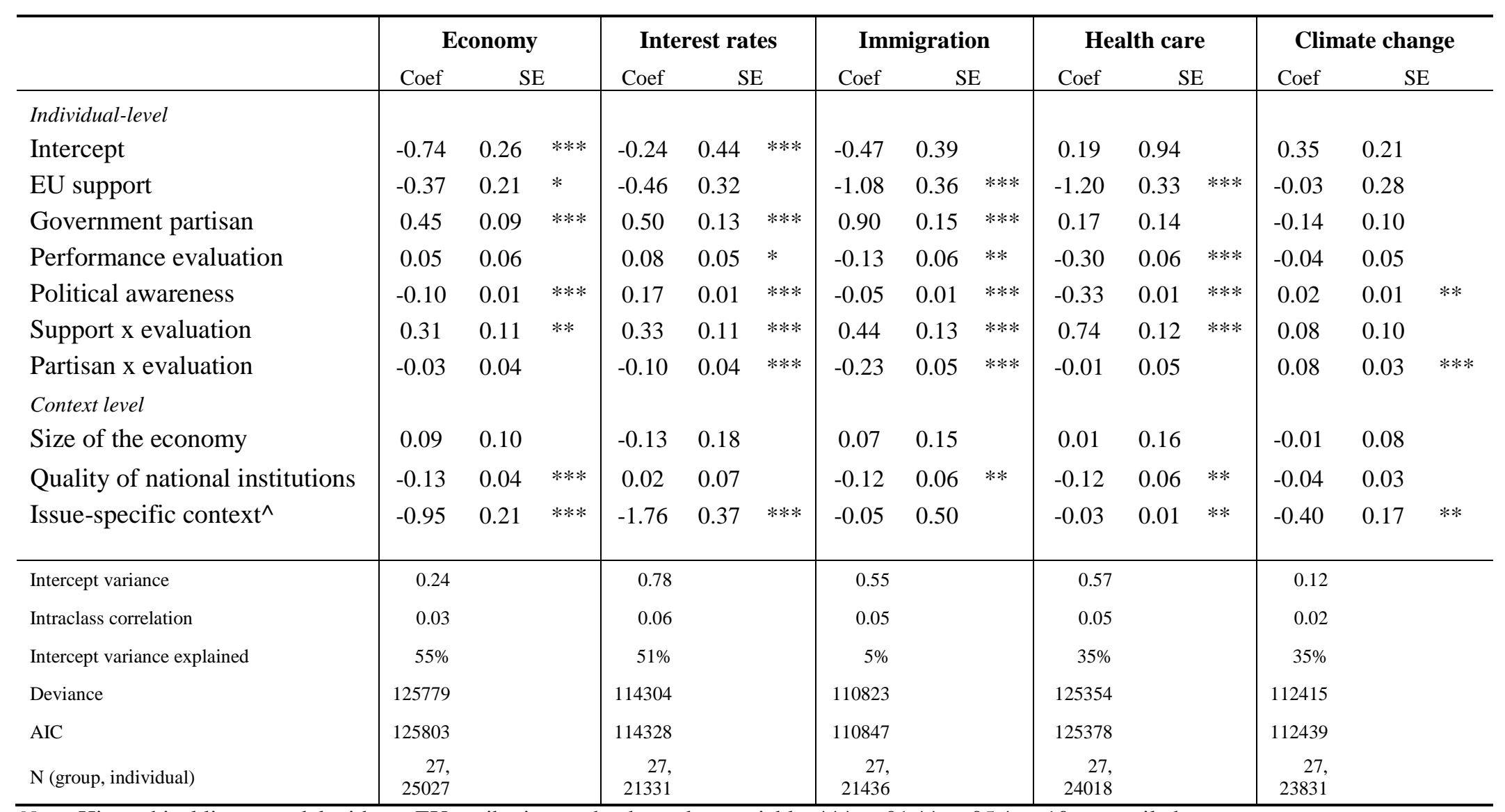

Note: Hierarchical linear model with net EU attribution as the dependent variable. ${ }^{* * *} \mathrm{p}<.01{ }^{* *} \mathrm{p}<.05 * \mathrm{p}<.10$, two-tailed test

$\wedge$ Issue-specific context: Eurozone outsider (Economy, Interest rates); opt-out related to immigration (Immigration); national government expenditure on health (Health care); National Adaptation Strategy (Climate change) 
Fig. 1a: The economy

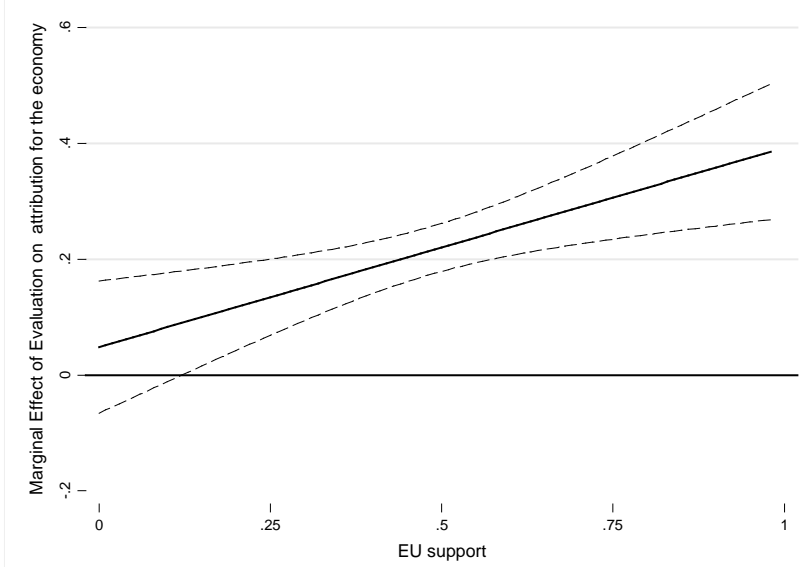

Fig. 1c: Immigration

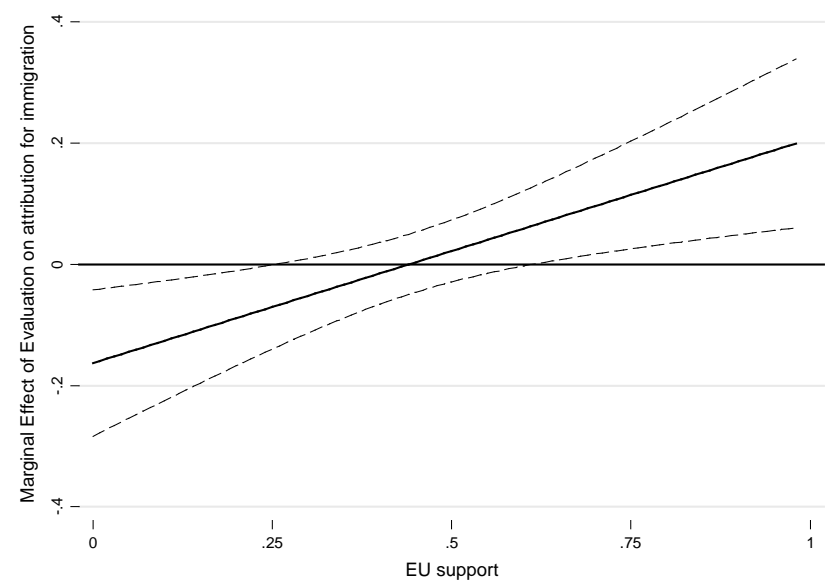

Fig. 1b: Interest rates

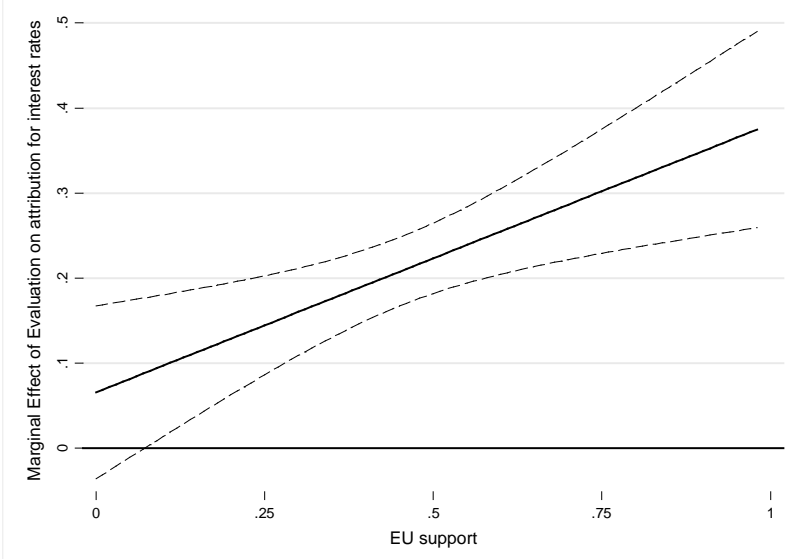

Fig. 1d: Health care

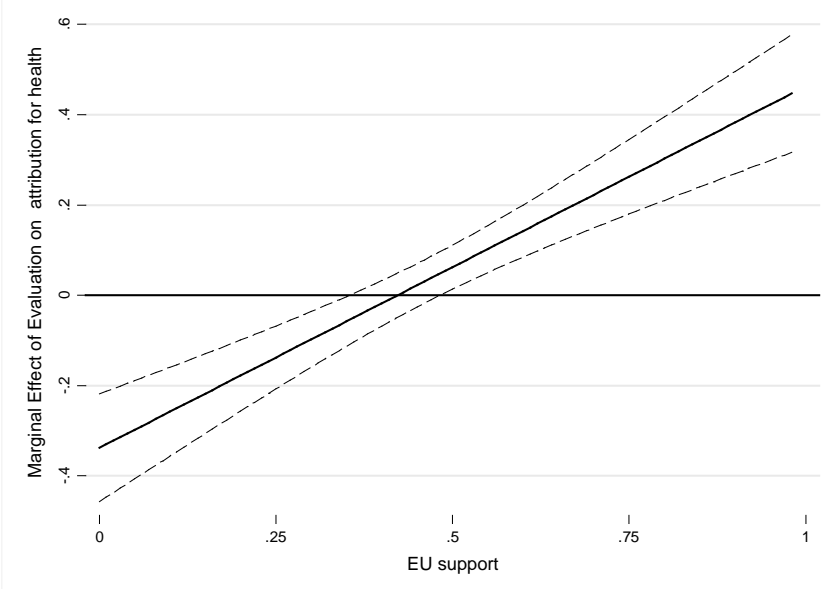

Figure 1: Marginal effect of performance evaluation on net EU attribution, by levels of EU support (with 95\% confidence intervals) 


\section{Endnotes}

${ }^{1}$ Other scholars have focused on how partisanship shapes economic evaluations directly. It has been argued that the causal arrow runs in the opposite direction to that posited in the classic economic voting model (Evans and Andersen, 2006; Wlezien et al. 1997), whereas others have disputed this (Lewis-Beck et al. 2008). This paper does not enter this debate, but focuses instead on how group-serving biases affect the attribution of responsibility.

${ }^{2}$ See Consolidated versions of the Treaty on European Union and the Treaty on the Functioning of the European Union, Title 1, Articles 2-6 (Official Journal C 115 of 9 May 2008).

${ }^{3}$ In areas of exclusive competences, the EU can make directives and conclude international agreements. In areas of shared competences, member states cannot exercise competence in areas where the EU has already done so. Finally, in areas of complementary competences, the EU's powers are limited to actions to support, coordinate or supplement member states' actions.

${ }^{4}$ In 2009 two countries, Denmark and the UK, had opt-outs from joining the Eurozone and Sweden had a de facto opt-out. Seven other member states were, at the time, obligated to join the zone once they fulfilled the entry (convergence) criteria.

${ }^{5}$ The competency of the EU in the area of fiscal policy has expanded over time. In response to the EU's sovereign debt crisis beginning in 2010 several measures have been adopted to reform the Eurozone's Stability and Growth Pact, and the economic governance of the Eurozone more generally, to ensure greater macroeconomic coordination at the European level.

${ }^{6}$ Some member states have negotiated certain opt-outs from legislation or treaties of the EU, meaning they do not have to fully participate in certain policy areas. Currently, five states have 
such opt-outs: Denmark (four opt-outs), Ireland (two opt-outs), Poland (one opt-out) Sweden (de facto opt-out from the Eurozone) and the United Kingdom (four opt-outs).

${ }^{7}$ Other factors, specifically utilitarian cost-benefit calculations, have also been shown to influence citizens’ support for the European Union (see Gabel 1998; McLaren 2006).

${ }^{8}$ There are other ways in which the dependent variable could be operationalized. The most obvious is to simply use the EU attribution scale (0-10) as the dependent variable. To check the robustness of our results, we also estimated our models using this alternative specification. As shown in Tables A2 in the appendix the substantive results produced when estimating the models below with this dependent variable are similar. In the article, we have chosen to use the 'net EU attribution' operationalization as our dependent variable as it most accurately captures the theoretical construct of attribution in a multilevel system of governance.

${ }^{9}$ This is an opinion that voters share with experts in EU policy-making. In an expert survey, conducted by the authors with identical survey items, $119 \mathrm{EU}$ experts from across the EU also ranked climate change as the policy area with highest (outside the Eurozone) or second highest (within the Eurozone, where interest rate policy is ranked higher) net EU attribution level.

${ }^{10}$ Previous models also included a range of other context-level controls that could have an impact on attribution: GDP per capita, age of democracy, EU accession year, a new member state dummy, clarity of responsibility at the national level, and Freedom House scores. None of these variables were statistically significant or changed the findings shown here.

${ }^{11}$ These items form a single dimension with a Cronbach’s alpha of 0.72 . See the appendix for details on question wording. 
${ }^{12}$ We find no differences to our substantive results, if we instead divide the variable into three groups: government partisan, opposition partisan and respondents with no partisanship. Hence, in our models we simply include a dummy for government partisan (coded 1) versus everyone else (coded 0).

${ }^{13}$ Other individual-level controls, such as age, class, income, gender and left-right ideology, were included in previous models, but they made no difference to the results presented here.

${ }^{14}$ To keep things simple we just hold all other variables at their mean, including partisanship which strictly speaking can only hold the value of zero or one.

${ }^{15}$ One explanation of this political sophistication effect is that it is simply magnifying the differences between issue areas that we see in Table 1. For the economy, immigration and healthcare, the average person thinks that national governments are more important than the EU, but this gap is even bigger for the most politically sophisticated people. For interest rates, the political sophistication effect is positive, but in fact this is heavily mediated by being in the Eurozone or not. For people living in Eurozone countries political sophistication has a positive effect on net EU attribution, and for those living in non-Eurozone countries, political sophistication generally has a negative effect. Finally, although the effect of political knowledge on perceived climate change responsibility is positive, it is also very small in comparison to the other effects. 